\title{
Assessing the knowledge of caregivers of children undergoing peritoneal dialysis in Riyadh, Saudi Arabia
}

\author{
Fatmah Abdullah Awaji, Nour Mahfouz Al Thibani, Nawal Abdulbagi Alsulami, Sarah Saad Al Otaibi, Salma Moawad \\ College of Nursing, King Saud University, Riyadh, Saudi Arabia
}

Received: April 25, 2018

DOI: $10.5430 /$ jnep.v9n1p44
Accepted: July 10, 2018

URL: https://doi.org/10.5430/jnep.v9n1p44

\begin{abstract}
Background and objective: Children with end stage renal disease (ESRD) are commonly placed onto chronic peritoneal dialysis (PD) while awaiting a transplant. Those children require a caregiver to assume major responsibility for their treatment. Knowledge of those caregivers is very important to prevent complications. This study aimed to assess the knowledge of caregivers of children undergoing PD in Riyadh.

Methods: A convenient sample of 41 caregivers of children on PD from three hospitals in Riyadh and who met the inclusion criteria participated in this study. Structured questions were developed by the researchers and used to collect data regarding the study that consisted of two parts. The first part included sociodemographic data of children and the caregivers. The second part contained 36 questions that assessed the knowledge of the caregivers.

Results: The majority of caregivers were mothers who were not working. All caregivers were educated, and most were from the central region of Riyadh. It was found that the caregivers had more knowledge than expected, the source of this knowledge was from physicians. There was a high correlation between the knowledge and education level of caregivers. Moreover, there was a significantly statistical correlation between correct answer and sociodemographic data of caregivers' water supply, type of services and distance between home and the nephrology center.

Conclusions and recommendations: Most caregivers have adequate knowledge regarding the care of children with ESRD; however, some weaknesses were identified. The caregivers do not know the symptoms of the disease and they are unable to identify signs of dehydration and the importance of weight to prevent dialysis complications. One third of the sample did not know about the complications of PD. We recommend frequent sessions of PD management and care.
\end{abstract}

Key Words: Caregivers, Level of knowledge, Peritoneal dialysis, Chronic kidney disease

\section{INTRODUCTION}

Chronic renal failure (CRF) is a disorder that is becoming more prevalent among all population groups worldwide; it is characterized by a drop in the glomerular filtration rate, causing the loss of the kidney's regulating, excretory and endocrine functions. ${ }^{[1]} \mathrm{CRF}$ occurs when the kidney has an issue relating to the concentration of urine, the maintenance of electrolytes, or if there is a protrusion of waste output. In children, renal failure can be severe or inveterate. ${ }^{[2]}$

For children with chronic kidney disease (CKD), they need medical treatment over their lifetime. This can cause significant discomfort and affect their daily routine and the lifestyle of their families. For children with CKD or peritoneal dialysis (PD), the management process is considered a highly complicated process. Commonly, it requires several medical

\footnotetext{
*Correspondence: Fatmah Abdullah Awaji; Email: fatmah_awaji@hotmail.com; Address: College of Nursing, King Saud University, Riyadh, Saudi Arabia.
} 
prescriptions, invasive procedures and nutrient supplements provided through the tubes of treatment devices. ${ }^{[3]}$

Based on dialysis statistics that are provided by the Saudi Center for Organ Transplantation (SCOT), by the end of 2016, 17,687 patients received dialysis, 16,315 were treated by hemodialysis (HD) and 1,372 were treated by PD. ${ }^{[4]}$

It has been projected that the number of patients with ESRD will increase by approximately $60 \%$ in 2020 compared to figures from 2005. ${ }^{[5]}$

To start PD, children need to be trained on how to perform dialysis at home. Understanding how to carry out dialysis is difficult for adults, but perhaps even more challenging for the parents of children needing it. Most reports agree that PD training programs continue to play an important role in pediatric PD. Several authors' correspondence suggest the need for an organized teaching protocol for the families of children with ESRD. ${ }^{[6]}$

On the contrary, a dialysis nurse, as a fundamental caregiver, has an essential role in providing constant evaluation, distinguishing the child's complaints about symptoms, providing constant support for medical strategies and providing the care in order to support the families of the children and assist them in exploring their emotions. ${ }^{\text {[7] }}$

The safety of the patient is an essential concern for all healthcare professionals, especially caregivers. They are permanently involved in the patient's care. ${ }^{[8]}$ However, it is important for nurses to develop their knowledge. Eventually, the knowledge of the caregivers is regarded as the heart and soul of every patient. Caregivers' knowledge and skills of practice play a fundamental role in containing and controlling the patients' well-being as this ultimately develops and enhances the quality of care for the patients.

Therefore, caregivers who lack knowledge can cause several issues, such as complications relating to the quality of care for children with PD. ${ }^{[1]}$ This study aims to assess the knowledge of Saudi caregivers of children undergoing PD in Riyadh.

\section{Research questions}

In order to fulfil the study aim, the following questions were developed:

(1) What are the sociodemographic characteristics of children with PD and their caregivers?

(2) What is the estimated level of knowledge of the caregivers?

(3) Is there a relationship between sociodemographic characteristics of the children and their caregivers' level of knowledge?

\section{STUdy METhOdology}

\subsection{Setting}

Patients were recruited from pediatric nephrology units in three major hospitals in Riyadh, Saudi Arabia that offer free medical services to people.

\subsection{Research design}

A quantitative descriptive cross-section research approach was adopted in this study.

\subsection{Subject}

\subsubsection{Sample type}

A sample of 41 caregivers of children on PD participated in this study, all of which met the inclusion criteria.

\subsubsection{Sample size}

A total sample of 41 caregivers out of 107 completed the questionnaire.

\subsubsection{Inclusion criteria}

Saudi caregivers of children undergoing PD.

\subsection{Tool of data collection}

\subsection{Data collection}

A structured interview questionnaire was developed after an extensive literature review and consultation with experts in the pediatric field. The questionnaire was modified as per the experts' suggestions. The modified, final version of the questionnaire was used in this study.

\subsection{Questionnaire content}

The questionnaire included multiple choice questions about the following points:

(1) Sociodemographic data of the children and caregivers.

(2) General information about the children's history of disease and family services provided.

(3) Management of PD, such as diet, catheter care and weight.

\subsection{Ethical consideration}

- An official letter from the King Saud University (KSU) Nursing College was obtained and submitted to the administration of the participating hospitals for permission to conduct the study.

- Ethical approval was received from the Research Ethics Committee of the Faculty of three hospitals in Riyadh.

- Consent was taken from the caregivers. 


\subsection{Pilot study}

A pilot study for the questionnaire was conducted before data was collected for this study. Data were analyzed using IBM SPSS software package version 20.0. Qualitative data was described using numbers and percentages. Quantitative data was described using means and standard deviations. Significance levels of the obtained results was set at the $5 \%$.

The tests used in this study were:

(1) Chi-squared test: For categorical variables, to compare the different groups.

(2) Monte Carlo correction: Correction of the chi-squared test when more than $20 \%$ of the cells had an expected count less than five.

\section{RESULTS}

\subsection{Socio-demographic data of the children}

Table 1 summarizes the characteristics of the pediatric PD patients, including age, gender, child birth order, educational level and age of disease diagnosis. Regarding age, this was grouped into five age categories: less than one-year old, between one and three-year old, between four and seven-year old, between eight and 12-year old and between 13 and 18year old. Most of the children were aged between 8 and 12 -year $(31.7 \%), 9.8 \%$ were less than one year, $22.0 \%$ were between one and three years, $22.0 \%$ were four to seven-years old and $14.6 \%$ were eight to 18 -year old. Regarding gender, $75.6 \%$ of the sample were male and $24.4 \%$ were female.

Concerning child birth order, about half of the children were the first born (46.3\%), 24.4\% were second, $17.1 \%$ were third, $9.8 \%$ were fourth and $2.4 \%$ were in the "other" category.

Regarding educational level, about half of the study's sample had no schooling (48.8\%), 39.0\% were primary-level educated, $7.3 \%$ were preparatory and $4.9 \%$ were secondary. The age of disease diagnosis was the fifth variable, and this was categorised into four groups: $48.8 \%$ were less than one-year old, $31.7 \%$ were one to three years, $7.3 \%$ were four to six years and $12.2 \%$ were older than six years.

Table 1. Socio-demographic data of the children

\begin{tabular}{|c|c|c|c|}
\hline Variable & Categories & Frequency & Percentage (\%) \\
\hline \multirow{5}{*}{ Child Age } & Less than 1 year & 4 & 9.8 \\
\hline & 1 to 3 years & 9 & 22.0 \\
\hline & 4 to 7 years & 9 & 22.0 \\
\hline & 8 to 12 years & 13 & 31.7 \\
\hline & 13 to 18 years & 6 & 14.6 \\
\hline \multirow{2}{*}{ Gender } & Male & 31 & 75.6 \\
\hline & Female & 10 & 24.4 \\
\hline \multirow{5}{*}{ Child birth order } & First & 19 & 46.3 \\
\hline & Second & 10 & 24.4 \\
\hline & Third & 7 & 17.1 \\
\hline & Fourth & 4 & 9.8 \\
\hline & Other & 1 & 2.4 \\
\hline \multirow{4}{*}{ Educational level } & Primary & 16 & 39.0 \\
\hline & Preparatory & 3 & 7.3 \\
\hline & Secondary & 2 & 4.9 \\
\hline & No schooling & 20 & 48.8 \\
\hline \multirow{4}{*}{ Age of disease diagnosis } & Less than 1 year & 20 & 48.8 \\
\hline & 1 to 3 years & 13 & 31.7 \\
\hline & 4 to 6 years & 3 & 7.3 \\
\hline & Older than 6 years & 5 & 12.2 \\
\hline
\end{tabular}

\subsection{Demographic data of caregivers}

Table 2 summarizes the caregivers' characteristics including age, gender, relation to the child, educational level, marital status, family type, family size, type of job, household income, family history regarding the disease, geographyregion, housing type and internal water supply. One third of caregivers' ages ranged between 25 and 34 years (36.6\%), $22.0 \%$ were aged between 18 and 24 years, $29.3 \%$ were aged between 35 and 44 years, and $12.2 \%$ were older than 45 years. Regarding gender, $12.2 \%$ of the caregivers were male, and $87.8 \%$ were female. Regarding the caregivers' relation to the child, $85.4 \%$ were their mother, $7.3 \%$ were their father, 
$2.4 \%$ were their child and $4.9 \%$ were their assistant. Regarding their educational level, $22.0 \%$ of the caregivers were in the category "read and write", $4.9 \%$ had completed primary school, $22.0 \%$ had completed secondary school, $34.1 \%$ were high-school graduates and $17.1 \%$ had a bachelor's degree. Most of the care givers were married (85.4\%), while $9.8 \%$ were separated and $4.9 \%$ were divorced. Regarding family type, $56.1 \%$ classified themselves in the "nuclear family" category, $39.0 \%$ in the "extended family", $2.4 \%$ in the "extended family", $2.4 \%$ in the "step-family" and $2.4 \%$ in the "grandparent" category. Regarding family size, $48.8 \%$ had a "small family" (parent/s and less than five children), $43.9 \%$ had a "big family" (parent/s and more than five children) and $7.3 \%$ in the "parent/s, children and one relative", i.e. grandmother, grandfather, uncle or aunty. In respect of employment, more than three quarters of the caregivers were "not working" $(80.5 \%)$, while $2.4 \%$ worked "office hours", $12.2 \%$ had "shift hours (eight hours)" and $4.9 \%$ had "shifting hours (12 hours)". Three quarters of the household incomes ranged between "3,000 to 8,000 SR" (73.2\%), while $9.8 \%$ had "less than 3,000 SR" and $17.1 \%$ earned between "9,000 to 14,000 SR". In relation to family history of the disease, $24.4 \%$ of the participants classified themselves as "first degree", $7.3 \%$ were "second degree" and $68.3 \%$ had "no history". Around half of the caregivers' geography-region was the "central region" $(48.8 \%)$, while $9.8 \%$ were from the "northern region", $19.5 \%$ from the "eastern region", $17.1 \%$ from the "western region" and $4.9 \%$ from the "southern region". Regarding housing type, $78.0 \%$ of the participants live in an "apartment", $17.1 \%$ live in a "villa" and $4.9 \%$ selected "other type". Concerning internal water supply, $87.8 \%$ of participants have a "piping system" and $12.2 \%$ have "no piping system".

\subsection{General information about PD issues}

Table 3 illustrates the caregivers' responses to general information about PD issues. $95.1 \%$ of participants selected "government hospital" as the type of facility their child seeks treatment at, $2.4 \%$ selected "private hospital" and $2.4 \%$ selected "Saudi Society of Nephrology". Regarding distance from the nephrology center, $2.4 \%$ of participants lived "less than $5 \mathrm{~km}$ ", $12.2 \%$ lived between " 5 and $10 \mathrm{~km}$ ", $24.4 \%$ lived between "5 and $15 \mathrm{~km}$ " and $61.0 \%$ lived "more than $15 \mathrm{~km}$ " away. More than half of the participants relay the selection of the option of the dialysis to doctor (58.5\%), while $7.3 \%$ from Select the option of the dialysis are "Mother", and $34.1 \%$ are "Child condition". Concerning the caregivers' support to the child, $43.9 \%$ from supports the child are "self-expression", $36.6 \%$ are "alleviating feeling" and $19.5 \%$ are "strength selfimage". About three quarters of the children perform PD on a daily basis $(73.2 \%)$, while $7.3 \%$ perform it "twice weekly"

Published by Sciedu Press and $19.5 \%$ selected "according to the child's case". Regarding the CRF source of information, $22.0 \%$ of participants selected "doctor", $14.6 \%$ chose the "nurse" option, $14.6 \%$ selected "health educator", $2.4 \%$ chose "friend" and $46.3 \%$ selected "other sources". Approximately three quarters of caregivers responded that their child has been admitted to hospital due to complications $(73.2 \%)$ and $26.8 \%$ selected "no complications" had been encountered. Concerning the list of associated health problems, 9.8\% identified "dental problems", $31.7 \%$ stated "high-blood pressure", 9.8\% chose "anemia", $41.5 \%$ selected "more than one problem" and $7.3 \%$ chose the "no problems" category.

Table 4 shows the difference between caregivers' understanding of the definition the disease; more than three quarters of the sample responded correctly $(82.9 \%)$, while $17.1 \%$ of the participants' responses were incorrect. Regarding the differences between acute and chronic diseases, $70.7 \%$ of the sample were aware, $17.1 \%$ were not and $12.2 \%$ did not know. Half of the sample thought that the main reason for CRF was diabetes (48.8\%), while $24.4 \%$ believed it to be high-blood pressure and $26.8 \%$ thought it was caused by infection. Regarding the effects of the disease on growth and development, a majority of the sample were aware of this $(73.2 \%), 14.6 \%$ were not and $12.2 \%$ were not sure. Regarding the long-term prognosis, $78.0 \%$ of the sample were aware, $12.2 \%$ were not and $9.8 \%$ were unsure. One third of the sample $(39.0 \%)$ believed that "urinating more or less than normal" was the most significant symptom of the disease, while $7.3 \%$ of participants thought "feeling tired", $19.5 \%$ thought "nausea and vomiting", 7.3\% thought "back pain", $12.2 \%$ believed "headaches", $7.3 \%$ thought "cyanosis" and $7.3 \%$ thought "coughing" were the reasons. Regarding monitoring the child's bodily fluids, $97.6 \%$ of the sample were aware this is important; however, $2.4 \%$ of participants did not know. The mean of dehydration for about one third of the sample $(34.1 \%)$ was "loss of weight", while $29.3 \%$ thought "tiredness or weakness", $31.7 \%$ thought "decreased urinary output", $2.4 \%$ thought "other reasons" and "do not know". Regarding the mean of fluid over weight, the participants responded as follows: $26.8 \%$ "increased weight", $73 \%$ "increased urinary output", $34.1 \%$ "swelling of ankles or fingers", 24.4\% "puffiness around the eyes" and 7.3\% "do not know". Two thirds of the sample (65.9\%) were aware that a consistent weight before and after dialysis is important; however, $24.1 \%$ were not aware. Concerning exercise, $36.6 \%$ of the sample agreed that children on PD must limit participating in sporting activities, but $63.4 \%$ did not agree or know this was important. For clinical visits, more than three quarters $(80.5 \%)$ of the sample agreed that it is important to bring the child's daily dialysis records, whereas $19.5 \%$ of participants did not know. 
Table 2. Demographic data of caregivers

\begin{tabular}{|c|c|c|c|}
\hline Variable & Categories & Frequency & Percentage (\%) \\
\hline \multirow{4}{*}{ Age } & 18 to 24 years & 9 & 22.0 \\
\hline & 25 to 34 years & 15 & 36.6 \\
\hline & 35 to 44 years & 12 & 29.3 \\
\hline & More than 45 years & 5 & 12.2 \\
\hline \multirow{2}{*}{ Gender } & Male & 5 & 12.2 \\
\hline & Female & 36 & 87.8 \\
\hline \multirow{5}{*}{ Relation to child } & Mother & 35 & 85.4 \\
\hline & Father & 3 & 7.3 \\
\hline & Child & 1 & 2.4 \\
\hline & Relative & 0 & 0.0 \\
\hline & Assistant & 2 & 4.9 \\
\hline \multirow{7}{*}{ Education level } & Illiterate & 0 & 0.0 \\
\hline & Read and write & 9 & 22.0 \\
\hline & Completed primary school & 2 & 4.9 \\
\hline & Completed secondary school & 9 & 22.0 \\
\hline & High school graduate & 14 & 34.1 \\
\hline & Bachelor's degree & 7 & 17.1 \\
\hline & Other advanced degree beyond a Bachelor’s degree & 0 & 0.0 \\
\hline \multirow{7}{*}{ Marital status } & Married & 35 & 85.4 \\
\hline & Separated & 4 & 9.8 \\
\hline & Divorced & 2 & 4.9 \\
\hline & Nuclear Family & 23 & 56.1 \\
\hline & Extended Family & 16 & 39.0 \\
\hline & Stepfamily & 1 & 2.4 \\
\hline & Grandparent Family & 1 & 2.4 \\
\hline \multirow{3}{*}{ Family size } & Small (parent and children less than 5) & 20 & 48.8 \\
\hline & Big (parent and children more than 5) & 18 & 43.9 \\
\hline & Parent, children and one of the relatives: grandmother, grandfather, uncle and aunty. & 3 & 7.3 \\
\hline \multirow{4}{*}{ Type of job } & Not working & 33 & 80.5 \\
\hline & Office hours & 1 & 2.4 \\
\hline & Shift of 8 hours & 5 & 12.2 \\
\hline & Shift of 12 hours & 2 & 4.9 \\
\hline \multirow{4}{*}{$\begin{array}{l}\text { Household } \\
\text { income }\end{array}$} & Less than 3,000 SR & 4 & 9.8 \\
\hline & 3,000 to $8,000 \mathrm{SR}$ & 30 & 73.2 \\
\hline & 9,000 to $14,000 \mathrm{SR}$ & 7 & 17.1 \\
\hline & 15,000 to 20,000 SR & 0 & 0.0 \\
\hline \multirow{3}{*}{$\begin{array}{l}\text { Family history } \\
\text { of the disease }\end{array}$} & There is no history & 28 & 68.3 \\
\hline & There is history from first degree & 10 & 24.4 \\
\hline & There is history from second degree & 3 & 7.3 \\
\hline \multirow{5}{*}{$\begin{array}{l}\text { Geography - } \\
\text { region }\end{array}$} & Central region & 20 & 48.8 \\
\hline & Northern region & 4 & 9.8 \\
\hline & Eastern region & 8 & 19.5 \\
\hline & Western region & 7 & 17.1 \\
\hline & Southern region & 2 & 4.9 \\
\hline \multirow{3}{*}{ Housing type } & Apartment & 32 & 78.0 \\
\hline & Villa & 7 & 17.1 \\
\hline & Other & 2 & 4.9 \\
\hline \multirow{2}{*}{$\begin{array}{l}\text { Internal water } \\
\text { supply }\end{array}$} & Piping system & 36 & 87.8 \\
\hline & No piping system & 5 & 12.2 \\
\hline
\end{tabular}

Table 5 illustrates that $87.8 \%$ of children require a restricted diet, but $12.2 \%$ do not or are unaware if they do. $80.5 \%$ from the fluid intake should not be excessive, but $19.5 \%$ "may be Excessive". $82.9 \%$ of children know that the types of food listed should be limited (bananas, oranges, cantaloupes, nectarines, baked potatoes, spinach, squash and tomato sauce) because they are rich in potassium, but $17.1 \%$ did not know. $85.4 \%$ of children knew they should eat enough protein, such 
as meat, poultry, fish, tofu and low sodium cottage cheese, fast foods and packaged or processed foods because they but $14.6 \%$ did not know. $70.7 \%$ of children know that phosphorus intake needs to be restricted, such as milk and dairy products, dried beans, peas, lentils, animal organs, whole wheat and processed foods containing additives, but $29.3 \%$ were unaware. $85.4 \%$ of children knew it was important to have low levels of salt in their diet, whereas $14.6 \%$ did not contain significant amounts of salt, but $24.4 \%$ did not know. $70.7 \%$ of children knew to minimize their sugar intake by eating fewer sweets and starchy food, such as baked goods, corn and potatoes, as well as keep active; however, 29.3\% did not know this. In general, $79.9 \%$ of the sample were know. $75.6 \%$ of children agreed that it is important to avoid aware of their dietary requirements, but $20.1 \%$ did not know.

Table 3. General information about PD issues

\begin{tabular}{|c|c|c|c|}
\hline Variable & Categories & Frequency & Percentage (\%) \\
\hline \multirow{3}{*}{ Type of facility your child visits } & Government hospital & 39 & 95.1 \\
\hline & Private hospital & 1 & 2.4 \\
\hline & Saudi Society of nephrology & 1 & 2.4 \\
\hline \multirow{4}{*}{ Distance from nephrology center } & Less than $5 \mathrm{~km}$ & 1 & 2.4 \\
\hline & 5 to $10 \mathrm{~km}$ & 5 & 12.2 \\
\hline & 5 to $15 \mathrm{~km}$ & 10 & 24.4 \\
\hline & More than $15 \mathrm{~km}$ & 25 & 61.0 \\
\hline \multirow{4}{*}{ Who selects the option of dialysis? } & Father & 0 & 0.0 \\
\hline & Mother & 3 & 7.3 \\
\hline & Child condition & 14 & 34.1 \\
\hline & Doctor & 24 & 58.5 \\
\hline \multirow{3}{*}{ How does the caregiver support the child? } & Self-expression & 18 & 43.9 \\
\hline & Alleviating feeling & 15 & 36.6 \\
\hline & Strength self-image & 8 & 19.5 \\
\hline \multirow{3}{*}{ How often does a child perform PD? } & Daily & 30 & 73.2 \\
\hline & Twice weekly & 3 & 7.3 \\
\hline & According to the child's case & 8 & 19.5 \\
\hline \multirow{7}{*}{ The source of information regarding CRF } & Doctor & 9 & 22.0 \\
\hline & Nurse & 6 & 14.6 \\
\hline & Health educator & 6 & 14.6 \\
\hline & TV & 0 & 0.0 \\
\hline & Friend & 1 & 2.4 \\
\hline & Education materials & 0 & 0.0 \\
\hline & Other & 19 & 46.3 \\
\hline \multirow{2}{*}{$\begin{array}{l}\text { Has your child been admitted to hospital due to any } \\
\text { complications? }\end{array}$} & Yes & 30 & 73.2 \\
\hline & No & 11 & 26.8 \\
\hline \multirow{5}{*}{ Does your child have any of the following problems? } & Dental problems & 4 & 9.8 \\
\hline & High blood pressure & 13 & 31.7 \\
\hline & Anemia & 4 & 9.8 \\
\hline & More than one problem & 17 & 41.5 \\
\hline & No & 3 & 7.3 \\
\hline
\end{tabular}

In addition, Table 5 illustrates that $97.5 \%$ of participants always handle their children's catheter with clean hands; however, $2.4 \%$ do not. $92.7 \%$ of the sample keep their children's exit site clean and dry, and $7.3 \%$ do not. $85.4 \%$ of participants inspect the catheter site for redness, swelling Published by Sciedu Press and pain, as well as cracks or holes in the catheter, whereas $14.7 \%$ do not. $75.6 \%$ of the sample inspect the catheter site for drainage on the dressing, and $24.2 \%$ do not. In general, $87.8 \%$ of the sample are aware of catheter care information; however, $12.2 \%$ do not. 
Table 4. Knowledge of caregivers regarding (disease and, monitoring the child's body fluids, exercise, and clinical visits)

\begin{tabular}{|c|c|c|c|}
\hline Variable & Categories & Frequency & Percentage (\%) \\
\hline \multirow{2}{*}{ What is the definition of your child's disease? } & Correct & 34 & 82.9 \\
\hline & Incorrect & 7 & 17.1 \\
\hline \multirow{3}{*}{$\begin{array}{l}\text { Do you know the difference between acute and chronic } \\
\text { diseases? }\end{array}$} & Yes & 29 & 70.7 \\
\hline & No & 7 & 17.1 \\
\hline & I do not know & 5 & 12.2 \\
\hline \multirow{7}{*}{ What do you think the main causes of CRF? } & High blood pressure & 10 & 24.4 \\
\hline & Diabetes & 20 & 48.8 \\
\hline & Infection & 11 & 26.8 \\
\hline & Birth defect & 0 & 0.0 \\
\hline & Trauma & 0 & 0.0 \\
\hline & Other & 0 & 0.0 \\
\hline & I do not know & 0 & 0.0 \\
\hline \multirow{3}{*}{$\begin{array}{l}\text { Do you know the effects of the disease on growth and } \\
\text { development? }\end{array}$} & Yes & 30 & 73.2 \\
\hline & No & 6 & 14.6 \\
\hline & I do not know & 5 & 12.2 \\
\hline \multirow{3}{*}{ Do you know that it has a long-term prognosis? } & Yes & 32 & 78.0 \\
\hline & No & 5 & 12.2 \\
\hline & I Do not know & 4 & 9.8 \\
\hline \multirow{7}{*}{ The symptoms of the disease } & $\begin{array}{l}\text { Urinating more than normal or less } \\
\text { than normal }\end{array}$ & 16 & 39.0 \\
\hline & Feeling tired & 3 & 7.3 \\
\hline & Nausea and vomiting & 8 & 19.5 \\
\hline & Back pain & 3 & 7.3 \\
\hline & Headache & 5 & 12.2 \\
\hline & Cyanosis & 3 & 7.3 \\
\hline & Cough & 3 & 7.3 \\
\hline
\end{tabular}

\begin{tabular}{c} 
Monitoring your child's bodily fluids \\
\hline Yes
\end{tabular}

\begin{tabular}{llll}
\hline \multirow{2}{*}{ Do you know it is important to keep monitoring your child's } & Yes & 40 & 97.6
\end{tabular}

bodily fluids?

What is the meaning of dehydration?

\begin{tabular}{lll}
\hline No & 0 & 0.0 \\
\hline I Do not know & 1 & 2.4 \\
\hline Loss of weight & 14 & 34.1 \\
\hline tiredness or weakness & 12 & 29.3 \\
\hline decreased urinary out put & 13 & 31.7 \\
\hline Other & 1 & 2.4 \\
\hline I do not know & 1 & 2.4 \\
\hline Increased weight & 11 & 26.8 \\
\hline increased urinary output & 3 & 7.3 \\
\hline Swelling of ankles or fingers & 14 & 34.1 \\
\hline puffiness around the eyes & 10 & 24.4 \\
\hline Other & 0 & 0.0 \\
\hline I do not know & 3 & 7.3 \\
\hline Yes & 27 & 65.9 \\
\hline No & 3 & 7.3 \\
\hline I do not know & 11 & 26.8 \\
\hline Yes & 15 & 36.6 \\
\hline No & 16 & 39.0 \\
\hline I do not know & 10 & 24.4 \\
\hline Yes & 33 & 80.5 \\
\hline No & 1 & 2.4 \\
\hline I do not know & 7 & 17.1 \\
\hline & & \\
\hline & & \\
\hline
\end{tabular}

Clinic Visit

Do you know that a consistent of weight of your child is important before and after dialysis?

Does your child on PD require restricted sports?

Clinic Visit


Table 5. Knowledge of caregivers regarding (diet, catheter care, weight, medications and common complications of PD)

\begin{tabular}{|c|c|c|c|c|c|c|c|c|c|}
\hline \multirow{2}{*}{ Field } & \multirow{2}{*}{ No. } & \multirow{2}{*}{ Items } & \multicolumn{2}{|l|}{ Yes } & \multicolumn{2}{|c|}{ No } & \multicolumn{2}{|c|}{ I do not know } & \multirow{2}{*}{ Rank } \\
\hline & & & $\mathbf{F}$ & $\%$ & $\mathbf{F}$ & $\%$ & $\mathbf{F}$ & $\%$ & \\
\hline \multirow{9}{*}{ Diet } & 1 & Does your child (patient) require a restricted diet? & 36 & 87.8 & 4 & 9.8 & 1 & 2.4 & 1 \\
\hline & 4 & $\begin{array}{l}\text { Do you know that your child should eat enough protein from meat, } \\
\text { poultry, fish, tofu, and low sodium cottage cheese? }\end{array}$ & 35 & 85.4 & 1 & 2.4 & 5 & 12.2 & 2 \\
\hline & 6 & $\begin{array}{l}\text { Do you know that it is important to limited levels of salt in your } \\
\text { child's diet? }\end{array}$ & 35 & 85.4 & 0 & 0.0 & 6 & 14.6 & 2 \\
\hline & 3 & $\begin{array}{l}\text { Do you know that the following types of food below should be } \\
\text { limited because it is rich in potassium? (banana, oranges, } \\
\text { cantaloupes and nectarines, baked potatoes, spinach, squash and } \\
\text { tomato sauce) }\end{array}$ & 34 & 82.9 & 0 & 0.0 & 7 & 17.1 & 3 \\
\hline & 2 & Should fluid intake not be excessive? & 33 & 80.5 & 6 & 14.6 & 2 & 4.9 & 4 \\
\hline & 7 & $\begin{array}{l}\text { Is it important to avoid most fast foods, packaged, and processed } \\
\text { foods because they contain significant amounts of salt? }\end{array}$ & 31 & 75.6 & 0 & 0.0 & 10 & 24.4 & 5 \\
\hline & 5 & $\begin{array}{l}\text { Do you know that phosphorus needs to be restricted, such as milk } \\
\text { and milk dairy products, dried beans, peas, lentils, animal organs, } \\
\text { whole wheat and processed foods containing phosphorus additives? }\end{array}$ & 29 & 70.7 & 4 & 9.8 & 8 & 19.5 & 6 \\
\hline & 8 & $\begin{array}{l}\text { Do you know that you can minimize the sugar intake in your child's } \\
\text { diet and keep them active by eating fewer sweets and starchy food, } \\
\text { such as baked goods, rice, corn or potatoes? }\end{array}$ & 29 & 70.7 & 2 & 4.9 & 10 & 24.4 & 6 \\
\hline & & Total & 262 & 79.9 & 17 & 5.2 & 49 & 14.9 & \\
\hline \multirow{5}{*}{ Catheter care } & 1 & Always handle your child's catheter with clean hand. & 40 & 97.6 & 0 & 0.0 & 1 & 2.4 & 1 \\
\hline & 2 & Keep your child exit site clean and dry. & 38 & 92.7 & 0 & 0.0 & 3 & 7.3 & 2 \\
\hline & 4 & $\begin{array}{l}\text { Inspect catheter site for redness, swelling or pain crackles or tiny } \\
\text { holes in the catheter }\end{array}$ & 35 & 85.4 & 4 & 9.8 & 2 & 4.9 & 3 \\
\hline & 3 & Inspect catheter site for drainage on dressing & 31 & 75.6 & 4 & 9.8 & 6 & 14.6 & 4 \\
\hline & & Total & 144 & 87.8 & 8 & 4.9 & 12 & 7.3 & \\
\hline \multirow{5}{*}{ Weight } & 1 & Is it very important to weigh your child at the same day every day? & 23 & 56.1 & 8 & 19.5 & 10 & 24.4 & 1 \\
\hline & 4 & Is it important to place the scales on a smooth, flat surface? & 22 & 53.7 & 4 & 9.8 & 15 & 36.5 & 2 \\
\hline & 3 & Is it important to use the same scales to measure your child's weight? & 21 & 51.2 & 8 & 19.5 & 12 & 29.3 & 3 \\
\hline & 2 & $\begin{array}{l}\text { Is it important to weigh your child wearing the same amount of } \\
\text { clothing? }\end{array}$ & 17 & 41.5 & 11 & 26.8 & 13 & 31.7 & 4 \\
\hline & & Total & 83 & 50.6 & 31 & 18.9 & 50 & 30.5 & \\
\hline \multirow{3}{*}{ Medications } & 1 & $\begin{array}{l}\text { Is it very important to take your child (patient) medications as } \\
\text { prescribed? }\end{array}$ & 36 & 87.8 & 2 & 4.9 & 3 & 7.3 & 1 \\
\hline & 2 & $\begin{array}{l}\text { Is it important to inform the health team if there are any unexpected } \\
\text { side effects from taking the medication? }\end{array}$ & 36 & 87.8 & 0 & 0.0 & 5 & 12.2 & 1 \\
\hline & & Total & 72 & 87.8 & 2 & 2.4 & 8 & 9.8 & \\
\hline \multirow{8}{*}{$\begin{array}{l}\text { Common } \\
\text { Complications } \\
\text { of PD }\end{array}$} & 4 & Had you notice any pinkish or bloody effluent? & 38 & 92.7 & 1 & 2.4 & 2 & 4.9 & 1 \\
\hline & 6 & $\begin{array}{l}\text { Pain during any part of your dialysis exchange, it is important to let } \\
\text { your dialysis team know? }\end{array}$ & 36 & 87.8 & 2 & 4.9 & 3 & 7.3 & 2 \\
\hline & 7 & $\begin{array}{l}\text { If the child develops any of complications, should the health care } \\
\text { center be informed? }\end{array}$ & 36 & 87.8 & 2 & 4.9 & 3 & 7.3 & 2 \\
\hline & 3 & $\begin{array}{l}\text { The nurse/doctor advises you as a caregiver when and how to add } \\
\text { Heparin into your dialysate if there is any blockage? }\end{array}$ & 35 & 85.4 & 1 & 2.4 & 5 & 12.2 & 3 \\
\hline & 1 & $\begin{array}{l}\text { The most common complication infections on PD are peritonitis and } \\
\text { exit site infection? }\end{array}$ & 34 & 82.9 & 2 & 4.9 & 5 & 12.2 & 4 \\
\hline & 5 & $\begin{array}{l}\text { Is a hernia a weak spot in the muscle of the abdomen or groin that is } \\
\text { evident as a bulge or a bump, considered as a complication of PD? }\end{array}$ & 28 & 68.3 & 0 & 0.0 & 13 & 31.7 & 5 \\
\hline & 2 & $\begin{array}{l}\text { Effluent fibrins, white stringy fibers can blocks the catheter and } \\
\text { block the flow of dialysate? }\end{array}$ & 26 & 63.4 & 2 & 4.9 & 13 & 31.7 & 6 \\
\hline & & Total & 233 & 81.2 & 10 & 3.5 & 44 & 15.3 & \\
\hline
\end{tabular}


Table 5 also illustrates that $56.1 \%$ of the sample agree that it is important to weigh their child at the same time, every day; however, $43.9 \%$ do not know. $53.7 \%$ of the sample agree that it is important to place the scales on a smooth, flat surface, and $46.3 \%$ do not know. $51.2 \%$ of the sample agree that it is important to use the same scales to weigh their child, and $48.8 \%$ do not know. $41.5 \%$ of the sample agree that it is important to weigh your child when they are wearing the same amount of the clothing, whereas $58.5 \%$ do not know. In general, $50.6 \%$ of the sample know the advantages of weighing their child, but $49.4 \%$ do not know about Catheter care.

Table 5 illustrates that $87.8 \%$ of the sample agree that it is important for their child (patient) to take their medication as prescribed, whilst $12.1 \%$ do not know. $87.8 \%$ of the sample agree that it is it important to inform the health team if there are any unexpected side effects from the medication, and $12.2 \%$ do not know. In general, $87.8 \%$ of the sample know information about their child's medication, but $12.2 \%$ do not know.

Table 5 shows that $92.7 \%$ of the sample notice pinkish or bloody effluent from their child, and $7.3 \%$ do not notice. $87.8 \%$ of the sample agree that if pain is experienced during any part of the dialysis exchange, it is important to inform the dialysis team; however, $12.2 \%$ do not know. $87.8 \%$ of the sample agree that if their child develops complications, the health team should be informed; however, $12.2 \%$ did not know. $85.4 \%$ of the sample agree that when and how caregiver need to add Heparin into the dialysate if there is any blockages as advised by nurse or doctor the nurse/doctor advised, and $14.6 \%$ do not know. $82.9 \%$ of the sample agree that the most common complications or infections related to PD are peritonitis and exit site infection, and $17.1 \%$ do not know. $68.3 \%$ of the sample agree that a hernia; a weak spot in the muscle of the abdomen or groin as represented by a bulge or bump, is considered as a complication of PD, and $31.7 \%$ do not know. $63.4 \%$ of the sample agree that effluent fibrins or white stringy fibers can block the catheter and flow of dialysate, and $36.6 \%$ do not know. In general, $81.2 \%$ of the sample know about common complications of PD, but $18.8 \%$ do not know any information about medications.

There is a significant correlation between the correct answers provided by the caregivers and their sociodemographic status. We used a chi-squared test to test the correlation between the correct answers and sociodemographic data of caregivers, and the results are presented in Table 6. It shows a significant correlation between the correct answers and the housing type and internal water supply variables since the $p$-value is equal to .006 and .006 , respectively, and this is $<.05$. There is no relation between the correct answers and the remaining variables as the $p$-value $>.05$.

Table 6. Correlation between the correct answers and sociodemographic data of caregivers

\begin{tabular}{lll}
\hline Socio-Demographic Data of Child & Chi-square test & $\boldsymbol{p}$-value \\
\hline Caregiver age & 0.507 & .086 \\
Gender & 0.034 & .853 \\
Relation to child & 1.178 & .758 \\
Education level & 8.263 & .082 \\
Marital status & 0.589 & .745 \\
Family type & 6.913 & .075 \\
Family size & 1.133 & .567 \\
Type of job & 0.677 & .877 \\
Household income & 1.800 & .407 \\
Family history of the disease & 5.130 & .077 \\
Geography-region & 3.011 & .556 \\
Housing type & 10.225 & .006 \\
Internal water supply & 7.411 & .006 \\
\hline
\end{tabular}

Table 7 indicates that most of the caregivers have excellent information ( $78.0 \%$ ) and $10 \%$ to $12 \%$ ranged from good to very good respectively.

Table 7. Distribution of the studied cases according to overall knowledge of caregivers $(n=41)$

\begin{tabular}{lll}
\hline Overall knowledge & No. & $\mathbf{\%}$ \\
\hline Poor: $0-12$ & 0 & 0.0 \\
Good: $13-25$ & 4 & 9.8 \\
Very good: $26-38$ & 5 & 12.2 \\
Excellent: $39-49$ & 32 & 78.0 \\
Total score & & \\
Min.-Max. & $21.0-49.0$ & \\
Mean \pm SD. & $41.05 \pm 7.94$ & \\
\hline
\end{tabular}

Table 8 shows that the only significant relationship was the education level of caregivers when using a chi-squared test $(11.089, p$-value $=.047)$.

Table 9 demonstrates that there was no significant relationship between the caregivers' overall knowledge and sociodemographic data. Table 10 illustrates that the only significant correlation of the caregivers' overall knowledge and sociodemographic data was evident in the internal water supply variable $(p$-value $=.009)$. Table 11 shows that a significant relationship between the caregivers' overall knowledge and general information about PD issues was evident in the type of facility offered by different agencies ( $p$-value $=.004$ ), and the distance between the nephrology center and home $(p$-value $<.001)$. 
Table 8. Relationship between overall knowledge of caregivers according to the sociodemographic data of child ( $\mathrm{n}=41)$

\begin{tabular}{|c|c|c|c|c|c|c|c|c|}
\hline & \multicolumn{6}{|c|}{ Overall knowledge } & \multirow{3}{*}{$\chi^{2}$} & \multirow{3}{*}{${ }^{\mathrm{MC}} \boldsymbol{p}$} \\
\hline & \multicolumn{2}{|c|}{$\begin{array}{l}\text { Good: } \\
13-25(n=4)\end{array}$} & \multicolumn{2}{|c|}{$\begin{array}{l}\text { Very good: } \\
26-38(n=5)\end{array}$} & \multicolumn{2}{|c|}{$\begin{array}{l}\text { Excellent: } \\
39-49(n=32)\end{array}$} & & \\
\hline & No. & $\%$ & No. & $\%$ & No. & $\%$ & & \\
\hline \multicolumn{9}{|l|}{ Child age } \\
\hline Less than 1 year & 1 & 25.0 & 0 & 0.0 & 3 & 9.4 & \multirow{5}{*}{4.967} & \multirow{5}{*}{.826} \\
\hline 1 to 3 years & 1 & 25.0 & 1 & 20.0 & 7 & 21.9 & & \\
\hline 4 to 7 years & 0 & 0.0 & 1 & 20.0 & 8 & 25.0 & & \\
\hline 8 to 12 years & 1 & 25.0 & 3 & 60.0 & 9 & 28.1 & & \\
\hline 13 to 18 years & 1 & 25.0 & 0 & 0.0 & 5 & 15.6 & & \\
\hline \multicolumn{7}{|l|}{ Gender } & \multirow{3}{*}{1.115} & \multirow{3}{*}{.812} \\
\hline Male & 4 & 100.0 & 4 & 80.0 & 23 & 71.9 & & \\
\hline Female & 0 & 0.0 & 1 & 20.0 & 9 & 28.1 & & \\
\hline \multicolumn{7}{|l|}{ Child birth order } & \multirow{6}{*}{12.176} & \multirow{6}{*}{.069} \\
\hline First & 0 & 0.0 & 1 & 20.0 & 18 & 56.3 & & \\
\hline Second & 1 & 25.0 & 2 & 40.0 & 7 & 21.9 & & \\
\hline Third & 2 & 50.0 & 2 & 40.0 & 3 & 9.4 & & \\
\hline Fourth & 1 & 25.0 & 0 & 0.0 & 3 & 9.4 & & \\
\hline Other & 0 & 0.0 & 0 & 0.0 & 1 & 3.1 & & \\
\hline \multicolumn{7}{|l|}{ Educational level } & \multirow{5}{*}{$11.089^{*}$} & \multirow{5}{*}{$.047^{*}$} \\
\hline Primary & 1 & 25.0 & 3 & 60.0 & 12 & 37.5 & & \\
\hline Preparatory & 2 & 50.0 & 0 & 0.0 & 1 & 3.1 & & \\
\hline Secondary & 0 & 0.0 & 1 & 20.0 & 1 & 3.1 & & \\
\hline No schooling & 1 & 25.0 & 1 & 20.0 & 18 & 56.3 & & \\
\hline \multicolumn{7}{|c|}{ The age of disease diagnosis } & \multirow{5}{*}{2.481} & \multirow{5}{*}{.913} \\
\hline Less than 1 year & 3 & 75.0 & 3 & 60.0 & 14 & 43.8 & & \\
\hline 1 to 3 years & 1 & 25.0 & 1 & 20.0 & 11 & 34.4 & & \\
\hline 4 to 6 years & 0 & 0.0 & 0 & 0.0 & 3 & 9.4 & & \\
\hline More than 6 years & 0 & 0.0 & 1 & 20.0 & 4 & 12.5 & & \\
\hline
\end{tabular}

Note. $\chi^{2}, p: \chi^{2}$ and $p$-values for the chi squared test; ${ }^{\mathrm{MC}} p: p$ value for Monte Carlo for the chi squared test; ${ }^{*} p \leq .05$.

\section{Discussion}

ESRD, as a chronic illness in children, is a serious, ongoing, physical health condition that has a range of relatively mild to severe or life-threatening disorders that continually or repeatedly disrupt normal development in relation to physical, emotional, psychological, social, economic and spiritual aspects. By nature, children are dependent physically, mentally and developmentally, so their family members play a great role and have a big responsibility for taking care of them, therefore, it is important to assess their knowledge. ${ }^{[3]}$

The findings from this study reflects that sociodemographic characteristics of the child age range from $8-12$ was $32 \%$, $87 \%$ male child nearly $50 \%$ do not register to school system and their age when the disease diagnosis less than one year (during infancy). The same result was supported by Published by Sciedu Press
El-Karmalawy et al. (2015) and Parham (2011). ${ }^{[3,9]}$ However, El Sayed's (2012) results contradict these findings. ${ }^{[10]}$ The results of this study indicated that the majority of children were males; this is supported by the study of Samra et al. (2009). ${ }^{[1]}$ However, this result is in contrast to ElKarmalawy et al.'s (2015) study; the majority of children were females. ${ }^{[3]}$ The children's education approved by results which showed that $39 \%$ of the children were at primary level; this is supported by Wong et al. (2014). ${ }^{[12]}$

The results of this study indicate that more than half of the caregivers' age ranges between 30 and 40; this result is supported by El-Karmalawy et al. (2015) and Parham (2011).${ }^{[3,9]}$ Mothers as responsible for the care of child it is observed in this study and other studies. This is likely due to the fact the females and mothers are naturally the care- 
givers in a family, unlike males. However, El-Karmalawy et half of the caregivers of children and adolescents undergoing al. (2015) illustrated that more than half of the caregivers hemodialysis or PD did not finish elementary school, and the were illiterate, unlike this current study that indicated that all caregivers could at least can read and write. ${ }^{[3]}$ Moreover, previous results showed that most of the caregivers were marthe study of Batista et al. (2016) showed that more than

Table 9. Relationship between the caregivers' overall knowledge and their sociodemographic data $(n=41)$

\begin{tabular}{|c|c|c|c|c|c|c|c|c|}
\hline & \multicolumn{6}{|c|}{ Overall knowledge } & \multirow{3}{*}{$\chi^{2}$} & \multirow{3}{*}{${ }^{\mathrm{MC}} p$} \\
\hline & \multicolumn{2}{|c|}{$\begin{array}{l}\text { Good: } \\
\text { 13-25 }(n=4)\end{array}$} & \multicolumn{2}{|c|}{$\begin{array}{l}\text { Very good: } \\
26-38(n=5)\end{array}$} & \multicolumn{2}{|c|}{$\begin{array}{l}\text { Excellent: } \\
39-49(n=32)\end{array}$} & & \\
\hline & No. & $\%$ & No. & $\%$ & No. & $\%$ & & \\
\hline \multicolumn{9}{|l|}{ Caregiver age } \\
\hline 18 to 24 years & 1 & 25.0 & 1 & 20.0 & 7 & 21.9 & \multirow{4}{*}{2.476} & \multirow{4}{*}{.960} \\
\hline 25 to 34 years & 1 & 25.0 & 2 & 40.0 & 12 & 37.5 & & \\
\hline 35 to 44 years & 2 & 50.0 & 2 & 40.0 & 8 & 25.0 & & \\
\hline More than 45 years & 0 & 0.0 & 0 & 0.0 & 5 & 15.6 & & \\
\hline \multicolumn{9}{|l|}{ Gender } \\
\hline Male & 1 & 25.0 & 1 & 20.0 & 3 & 9.4 & \multirow[t]{2}{*}{2.089} & \multirow[t]{2}{*}{.302} \\
\hline Female & 3 & 75.0 & 4 & 80.0 & 29 & 90.6 & & \\
\hline \multicolumn{9}{|l|}{ Relation to child } \\
\hline Mother & 3 & 75.0 & 4 & 80.0 & 28 & 87.5 & \multirow{4}{*}{8.014} & \multirow{4}{*}{.245} \\
\hline Feather & 1 & 25.0 & 0 & 0.0 & 2 & 6.3 & & \\
\hline Child & 0 & 0.0 & 1 & 20.0 & 0 & 0.0 & & \\
\hline Assistant & 0 & 0.0 & 0 & 0.0 & 2 & 6.3 & & \\
\hline \multicolumn{9}{|l|}{ Education level } \\
\hline Read and write & 2 & 50.0 & 2 & 40.0 & 5 & 15.6 & \multirow{5}{*}{5.316} & \multirow{5}{*}{.787} \\
\hline Completed primary school & 0 & 0.0 & 0 & 0.0 & 2 & 6.3 & & \\
\hline Completed secondary school & 1 & 25.0 & 1 & 20.0 & 7 & 21.9 & & \\
\hline High school graduate & 1 & 25.0 & 2 & 40.0 & 11 & 34.4 & & \\
\hline Bachelor's degree & 0 & 0.0 & 0 & 0.0 & 7 & 21.9 & & \\
\hline \multicolumn{9}{|l|}{ Marital status } \\
\hline Married & 3 & 75.0 & 4 & 80.0 & 28 & 87.5 & \multirow{3}{*}{4.474} & \multirow{3}{*}{.333} \\
\hline Separated & 1 & 25.0 & 0 & 0.0 & 3 & 9.4 & & \\
\hline Divorced & 0 & 0.0 & 1 & 20.0 & 1 & 3.1 & & \\
\hline \multicolumn{9}{|l|}{ Family type } \\
\hline Nuclear Family & 2 & 50.0 & 2 & 40.0 & 19 & 59.4 & \multirow{4}{*}{8.096} & \multirow{4}{*}{.308} \\
\hline Extended Family & 1 & 25.0 & 3 & 60.0 & 12 & 37.5 & & \\
\hline Stepfamily & 1 & 25.0 & 0 & 0.0 & 0 & 0.0 & & \\
\hline Grandparent Family & 0 & 0.0 & 0 & 0.0 & 1 & 3.1 & & \\
\hline \multicolumn{9}{|l|}{ Family size } \\
\hline Small (parent and children less than 5) & 1 & 25.0 & 1 & 20.0 & 18 & 56.3 & \multirow{3}{*}{6.306} & \multirow{3}{*}{.155} \\
\hline Big (parent and children more than 5) & 2 & 50.0 & 3 & 60.0 & 13 & 40.6 & & \\
\hline $\begin{array}{l}\text { Parent, children and one of the relative } \\
\text { grandmother, grandfather, uncle and aunty. }\end{array}$ & 1 & 25.0 & 1 & 20.0 & 1 & 3.1 & & \\
\hline
\end{tabular}


Table 10. Relationship between the caregivers' overall knowledge and sociodemographic data $(\mathrm{n}=41)$ "continue"

\begin{tabular}{|c|c|c|c|c|c|c|c|c|}
\hline & \multicolumn{6}{|c|}{ Overall knowledge } & \multirow{3}{*}{$\chi^{2}$} & \multirow{3}{*}{${ }^{\mathrm{MC}} p$} \\
\hline & \multicolumn{2}{|c|}{$\begin{array}{l}\text { Good: } \\
13-25(n=4)\end{array}$} & \multicolumn{2}{|c|}{$\begin{array}{l}\text { Very good: } \\
26-38(n=5)\end{array}$} & \multicolumn{2}{|c|}{$\begin{array}{l}\text { Excellent: } \\
39-49(\mathrm{n}=32)\end{array}$} & & \\
\hline & No. & $\%$ & No. & $\%$ & No. & $\%$ & & \\
\hline \multicolumn{9}{|l|}{ Type of job } \\
\hline Not working & 3 & 75.0 & 5 & 100.0 & 25 & 78.1 & \multirow{4}{*}{3.699} & \multirow{4}{*}{.776} \\
\hline Office hours & 0 & 0.0 & 0 & 0.0 & 1 & 3.1 & & \\
\hline Shifting 8 hours & 1 & 25.0 & 0 & 0.0 & 4 & 12.5 & & \\
\hline Other & 0 & 0.0 & 0 & 0.0 & 2 & 6.3 & & \\
\hline \multicolumn{7}{|l|}{ Household income } & \multirow{4}{*}{1.350} & \multirow{4}{*}{1.000} \\
\hline Less than $3,000 \mathrm{SR}$ & 0 & 0.0 & 0 & 0.0 & 4 & 12.5 & & \\
\hline 3,000 to $8,000 \mathrm{SR}$ & 3 & 75.0 & 4 & 80.0 & 23 & 71.9 & & \\
\hline 9,000 to $14,000 \mathrm{SR}$ & 1 & 25.0 & 1 & 20.0 & 5 & 15.6 & & \\
\hline \multicolumn{7}{|l|}{ Family history with the disease } & \multirow{4}{*}{2.122} & \multirow{4}{*}{.809} \\
\hline There is no history & 3 & 75.0 & 3 & 60.0 & 22 & 68.8 & & \\
\hline There is history from first degree & 1 & 25.0 & 1 & 20.0 & 8 & 25.0 & & \\
\hline There is history from second degree & 0 & 0.0 & 1 & 20.0 & 2 & 6.3 & & \\
\hline \multicolumn{7}{|l|}{ Geography-region } & \multirow{6}{*}{9.051} & \multirow{6}{*}{.217} \\
\hline Central region & 1 & 25.0 & 3 & 60.0 & 16 & 50.0 & & \\
\hline Northern region & 1 & 25.0 & 0 & 0.0 & 3 & 9.4 & & \\
\hline Eastern region & 0 & 0.0 & 0 & 0.0 & 8 & 25.0 & & \\
\hline Western region & 2 & 50.0 & 2 & 40.0 & 3 & 9.4 & & \\
\hline Southern region & 0 & 0.0 & 0 & 0.0 & 2 & 6.3 & & \\
\hline \multicolumn{7}{|l|}{ Housing type } & \multirow{4}{*}{4.534} & \multirow{4}{*}{.227} \\
\hline Apartment & 2 & 50.0 & 4 & 80.0 & 26 & 81.3 & & \\
\hline Villa & 1 & 25.0 & 1 & 20.0 & 5 & 15.6 & & \\
\hline Other & 1 & 25.0 & 0 & 0.0 & 1 & 3.1 & & \\
\hline \multicolumn{7}{|l|}{ Internal water supply } & \multirow{3}{*}{$9.913^{*}$} & \multirow{3}{*}{$.009 *$} \\
\hline Piping system & 1 & 25.0 & 5 & 100.0 & 30 & 93.8 & & \\
\hline No piping system & 3 & 75.0 & 0 & 0.0 & 2 & 6.3 & & \\
\hline
\end{tabular}

Note. $\chi^{2}, p: \chi^{2}$ and $p$ values for the chi squared test; ${ }^{\mathrm{MC}} p: p$ value for Monte Carlo for the chi squared test; ${ }^{*} p \leq .05$.

Generally, the results of this study show that most of the children come from a nuclear family, the mother is a housewife and the joint income ranges between 800 and 2,000\$; this is similar to the El- Karmalawy et al. (2015) study. ${ }^{[3]}$ Bhatti et al. (2012) contradicted this result as he found that $65 \%$ of children were living in extended families. ${ }^{[13]} \mathrm{His}$ findings also showed that $68 \%$ of children had no family history of the disease; this is supported by El-Karmalawy et al. (2015). ${ }^{[3]}$ Thus, this study indicated that the majority of caregivers live in an apartment; however, this contradicts the Batista et al. (2016) study that indicated $90 \%$ of children and adolescents undergoing hemodialysis or PD lived in a villa and $10 \%$ lived in an apartment. Furthermore, the results also indicate that most of the household had a piping system in

Published by Sciedu Press villas; this finding is supported by Batista et al. (2016). ${ }^{[1]}$

The results of this study showed that $95 \%$ of the children visit government hospitals to undergo hemodialysis; the philosophy of the Saudi Government is every citizen has the right to access healthcare.

The results showed that more than $61 \%$ of the caregivers and children have to travel more than $15 \mathrm{~km}$ in order to get to their nephrology center; this finding contradicts Morton et al. (2011) who stated that patients and caregivers have to travel only $10 \mathrm{~km} .{ }^{[14]}$ Therefore, a close proximity to chronic dialysis services would ease the travel burden on patients with ESRD and researchers recommended that the $\mathrm{MOH}$ increase the number of PD centers to decrease risk of complications of this type of this treatment. 
Table 11. Relationship between the overall knowledge and general information about PD issues $(n=41)$

\begin{tabular}{|c|c|c|c|c|c|c|c|c|}
\hline & \multicolumn{6}{|c|}{ Overall knowledge } & \multirow{3}{*}{$\chi^{2}$} & \multirow{3}{*}{${ }^{\mathrm{MC}} \boldsymbol{p}$} \\
\hline & \multicolumn{2}{|c|}{$\begin{array}{l}\text { Good: } \\
13-25(n=4)\end{array}$} & \multicolumn{2}{|c|}{$\begin{array}{l}\text { Very good: } \\
26-38(n=5)\end{array}$} & \multicolumn{2}{|c|}{$\begin{array}{l}\text { Excellent: } \\
39-49(\mathrm{n}=32)\end{array}$} & & \\
\hline & No. & $\%$ & No. & $\%$ & No. & $\%$ & & \\
\hline \multicolumn{9}{|l|}{ Type of facility your child visits } \\
\hline Government hospital & 3 & 75.0 & 4 & 80.0 & 32 & 100.0 & \multirow{3}{*}{$10.920 *$} & \multirow{3}{*}{$.044 *$} \\
\hline Private hospital & 1 & 25.0 & 0 & 0.0 & 0 & 0.0 & & \\
\hline Saudi Society of Nephrology & 0 & 0.0 & 1 & 20.0 & 0 & 0.0 & & \\
\hline \multicolumn{7}{|l|}{ Distance from nephrology center } & \multirow{5}{*}{$22.382 *$} & \multirow{5}{*}{$<.001 *$} \\
\hline Less than $5 \mathrm{~km}$ & 0 & 0.0 & 0 & 0.0 & 1 & 3.1 & & \\
\hline 5 to $10 \mathrm{~km}$ & 3 & 75.0 & 2 & 40.0 & 0 & 0.0 & & \\
\hline 5 to $15 \mathrm{~km}$ & 1 & 25.0 & 2 & 40.0 & 7 & 21.9 & & \\
\hline More than $15 \mathrm{~km}$ & 0 & 0.0 & 1 & 20.0 & 24 & 75.0 & & \\
\hline \multicolumn{7}{|l|}{ Who selects the option of dialysis? } & \multirow{4}{*}{1.596} & \multirow{4}{*}{.881} \\
\hline Mother & 0 & 0.0 & 0 & 0.0 & 3 & 9.4 & & \\
\hline Child & 1 & 25.0 & 1 & 20.0 & 12 & 37.5 & & \\
\hline Doctor & 3 & 75.0 & 4 & 80.0 & 17 & 53.1 & & \\
\hline \multicolumn{7}{|c|}{ How does the caregiver support the child? } & \multirow{4}{*}{3.173} & \multirow{4}{*}{.524} \\
\hline Self-expression & 2 & 50.0 & 4 & 80.0 & 12 & 37.5 & & \\
\hline Alleviating feeling & 1 & 25.0 & 1 & 20.0 & 13 & 40.6 & & \\
\hline Strength self-image & 1 & 25.0 & 0 & 0.0 & 7 & 21.9 & & \\
\hline \multicolumn{7}{|c|}{ The source of information used for CRF } & \multirow{4}{*}{7.445} & \multirow{4}{*}{.064} \\
\hline Doctor & 2 & 50.0 & 2 & 40.0 & 26 & 81.3 & & \\
\hline Nurse & 1 & 25.0 & 1 & 20.0 & 1 & 3.1 & & \\
\hline Health educator & 1 & 25.0 & 2 & 40.0 & 5 & 15.6 & & \\
\hline \multicolumn{9}{|c|}{ Has your child been admitted due to any complications? } \\
\hline Yes & 1 & 25.0 & 1 & 20.0 & 7 & 21.9 & \multirow{3}{*}{1.139} & \multirow{3}{*}{1.000} \\
\hline No & 3 & 75.0 & 3 & 60.0 & 20 & 62.5 & & \\
\hline If yes, how many times? & 0 & 0.0 & 1 & 20.0 & 5 & 15.6 & & \\
\hline \multicolumn{7}{|c|}{ Does your child have any of the following problems? } & \multirow{3}{*}{4.957} & \\
\hline Dental problems & 2 & 50.0 & 2 & 40.0 & 26 & 81.3 & & .061 \\
\hline High blood pressure & 2 & 50.0 & 3 & 60.0 & 6 & 18.8 & & \\
\hline The symptoms of the disease & $(n=$ & & $(\mathrm{n}=$ & & $(n=$ & & & \\
\hline Urinating more or less than normal & 0 & 0.0 & 0 & 0.0 & 2 & 13.3 & & \\
\hline Feeling tired & 1 & 100.0 & 1 & 100.0 & 5 & 33.3 & 610 & $10 \Omega 0$ \\
\hline Nausea and vomiting & 0 & 0.0 & 0 & 0.0 & 1 & 6.7 & 1.018 & 1.000 \\
\hline Back pain & 0 & 0.0 & 0 & 0.0 & 3 & 20.0 & & \\
\hline Headache & 0 & 0.0 & 0 & 0.0 & 4 & 26.7 & & \\
\hline
\end{tabular}

Note. $\chi^{2}, p: \chi^{2}$ and $p$ values for the chi squared test; ${ }^{\mathrm{MC}} p: p$ value for Monte Carlo for the chi squared test; ${ }^{*} p \leq .05$.

The findings revealed that $43 \%$ of caregivers support their child by self-expression and $36 \%$ do so by alleviating feelings; this result is supported by Low et al. (2009) and Mashayekhi et al. (2015). ${ }^{[15,16]}$

Regarding catheter care, most of the participants have good knowledge about it (87\%); this result is consistent with the study by Batista et al. (2016). ${ }^{11]}$ Although, the caregiver's knowledge on nutrition, medication and complications relating to PD is high; approximately $17 \%-30 \%$ of the participants have poor/inadequate knowledge about fluid intake and 
food restrictions, such as sugar, milk, dairy products, beans, peas, salt, packaged and processed food, as well as medication and the associated complications of PD. The same results were found by Kamal (2007) and Banchit (2003). ${ }^{[17,18]}$

Doctors and nurses represent only $37 \%$ of the source of ESRD information; this is serious as they provide the most amount of information to small communities and should be given more time to provide clarification, repetition and reinforcement of information.

\section{Conclusion}

Based on the results of this study, it was found that the majority of caregivers were females, mothers of the children and not working. All of the caregivers were educated and most of them were from the central region of Riyadh. It was also found that their overall level of knowledge was excellent.

\section{Recommendation}

(1) Continuous educational programs for all patients receiving hemodialysis and their families to improve their knowledge about treatment and self-care.

(2) Provision of self-care booklets to patients undergoing hemodialysis should be available in all hemodialysis units and given to all newly admitted patients.

\section{CONFlicts of InTEREST Disclosure}

The authors declare that there is no conflict of interest.

\section{REFERENCES}

[1] Batista A, Caminha C, de Fatima M, et al. Knowledge, attitudes and practice by caregivers of children and adolescents undergoing hemodialysis or peritoneal dialysis. Revista Electronica de Enfermagem. 2016.

[2] Kyle T, Carman S. Essentials of Pediatric Nursing. 2nd ed. Philadelphia: Wolters Kluwer/Lippincott Williams and Wilkins. 2013.

[3] El-Karmalawy E, Habib N, Fadel F, et al. Knowledge, attitudes and practices of caregivers of children with end stage renal disease on hemodialysis at Abu El Rish Pediatric University Hospital. Egyptian Nursing Journal. 2015.

[4] Saudi Center for Organ Transplantation (SCOT). Saudi Journal of Kidney Diseases and Transplantation. Saudi Center for Organ Transplantation. 2017.

[5] Bayoumi M, Al Harbi A, Al Suwaida A, et al. Predictors of quality of life in hemodialysis patients. Saudi Journal of Kidney Diseases and Transplantation. 2013; 24(2): 254. PMid:23538347 https : //doi.org/10.4103/1319-2442.109566

[6] Abu-Ouf NM, Abualhamyl AS, AlJahdali NF, et al. Parental perceptions of their child's kidney disease. Current Pediatric Research. 2016.

[7] McHugh MD, Lake ET. Understanding clinical expertise: nurse education, experience and the hospital context. Research in Nursing \& Health. 2001.

[8] McGaw C, Tennant I, Harding H, et al. Healthcare workers' attitudes to and compliance with infection control guidelines in the operating department at the university hospital of the West Indies, Jamaica. International Journal Of Infection Control. 2012; 8(3).

[9] Parham R. Caregivers burden in pediatric chronic kidney disease, salomons. Canterbury Christ Church University. 2011.
[10] El Sayed E. Effect of nursing intervention on the quality of life of children undergoing hemodialysis. Life Science Journal. 2012; 9(1): 77-86.

[11] Samra N. Prevalence of viral infection among Egyptian children with end stage renal disease. Australian Journal of Basic and Applied Sciences. 2009; 3(4): 3479-3491.

[12] Wong G, Medway M, Didsbury M, et al. Health and wealth in children and adolescents with chronic kidney disease. BMC Public Health. 2014; 14(1): 1-5.

[13] Bhatti A, et al. Socioeconomic impact of hemodialysis on patient undergoing dialysis at DHQ teaching hospital, Sargodha. Professional Medicine Journal. 2012; 19(4): 573-580.

[14] Morton R, Tong A, Webster A, et al. Characteristics of dialysis important to patients and family caregivers: a mixed methods approach. Nephrol Dial Transplant. 2011; 26: 4038-4046. PMid:21482637 https://doi.org/10.1093/ndt/gfr177

[15] Low J, Smith G, Burns A, et al. The impact of end-stage kidney disease (ESKD) on close persons: a literature review. NDT Plus. 2008; 1(2): 67-79.

[16] Mashayekhi F, Pilevarzadeh M, Rafati F. The assessment of caregiver burden in caregivers of hemodialysis patients. Mater Sociomed. 2015; 27(5): 333-6. PMid:26622201 https://doi .org/10.5455/msm. 2015. 27.333-336

[17] Kamal A. Quality of life of patients with end stage renal disease Thesis for Degree of M.Sc.N. Medical Surgical Nursing, Faculty of Nursing, Cairo University. 2017. 140-152 p.

[18] Chokephichit P. Self-care of Chronic Renal Failure Patients Undergoing Hemodialysis. Mahidol University. 2013. 